\title{
PENGARUH PENGENDALIAN DIRI DAN PERILAKU BELAJAR TERHADAP TINGKAT PEMAHAMAN PENGANTAR AKUNTANSI \\ (Studi Empiris Pada Mahasiswa Program Studi Akuntansi Fakultas Ekonomi Universitas Prof. Hazairin SH Kota Bengkulu)
}

\author{
Pedi Riswandi \\ Fakultas Ekonomi Universitas Prof. Hazairin SH Bengkulu
}

\begin{abstract}
ABSTRAK
Pedi Riswandi; Tujuan penelitian ini adalah untuk mengetahui pengaruh pengendalian diri dan perilaku belajar terhadap tingkat pemahaman pengantar akuntansi pada mahasiswa program studi akuntansi Universitas Prof. Hazairin Kota Bengkulu. Jenis penelitian yang digunakan dalam penelitian ini adalah deskriptif kuantitatif yaitu penelitian yang berusaha untuk menuturkan pemecahan masalah yang ada sekarang berdasarkan data-data serta menyajikan data, menganalisis dan menginterprestasikannya. Objek penelitian dalam penelitian ini adalah mahasiswa S1 akuntansi angkatan 2011 dan 2012. Hasil penelitian Pengendalian diri berpengaruh dan signifikan terhadap tingkat pemahaman akuntansi, hal ini ditunjukkan dengan nilai koefisien $\beta$ sebesar 0,136 pada tingkat signifikan 0,007. Perilaku Belajar berpengaruh dan tidak signifikan terhadap tingkat pemahaman akuntansi, hal ini ditunjukkan dengan nilai koefisien $\beta$ sebesar 0,058 pada tingkat signifikan 0,420, Dengan ditolaknya hipotesis ini berarti variabel perilaku belajar belum bisa dijadikan ukuran dalam tingkat pemahaman akuntansi. Pengendalian diri dan Perilaku Belajar berpengaruh dan signfikan terhadap tingkat pemahaman akuntansi bahwa nilai pseudo R-Square Nagelkerke sebesar 0,968. Hal ini berarti bahwa variabel pengendalian diri dan perilaku belajar dapat dijelaskan dalam penelitian ini sebesar 96,8\% sedangkan sisanya sebesar 3,2\% dijelaskan oleh variabel lain yang tidak dimasukkan dalam penelitian ini.
\end{abstract}

\section{ABSTRACT}

Pedi Riswandi; The purpose of this study was to determine the effect of self-control and behavioral study of the level of understanding of the accounting introductory accounting students of the University Prof. Hazarin city of Bengkulu. This type of research used in this research is quantitative descriptive research that seeks to said solving the existing problems based on the data and presents the data, analyze and interpret. The object of this research is accounting S1 student class of 2011 and 2012. The results of self control and significant influence on the level of understanding of accounting, as shown by the coefficient $\beta$ of 0.136 at a significant level of 0.007.

Learning behavior and no significant effect on the level of understanding of accounting, as shown by the coefficient $\beta$ of 0.058 at a significant level of 0.420, the rejection of this hypothesis means learning behavior variables can not be used as benchmarks in the level of understanding of accounting. Restraint and Behavior Learning and were significant influence on the level of understanding of accounting that values Nagelkerke pseudo R-square of 0.968 This means that the variable self-control and learning behavior can be explained in this study amounted to $96.8 \%$ while the remaining $3.2 \%$ is explained by Other variables that were not included in this study.

Key words: self-control, learning behavior

\section{PENDAHULUAN}

Salah satu langkah yang dilakukan oleh Pemerintah untuk meningkatkan taraf hidup yang lebih baik adalah pendidikan. Pendidikan memegang peranan penting dalam menciptakan bertingkah laku, mental dan seluruh aspek kehidupan suatu negara karena pendidikan 
merupakan tolak ukur yang menentukan maju atau mundur proses pembangunan Negara dalam segala bidang.

Sesuai dengan Undang-undang Dasar 1945 pasal 31, dimana penyelenggaraan pendidikan di Indonesia minimal Sembilan tahun ( SD sampai SMP). Pendidikan jenjang selanjutnya adalah SMA dan Perguruan Tinggi. Proses belajar mengajar di perguruan tinggi menuntut mahasiswa untuk mencapai pembelajaran yang optimal dengan melakukan penekanan pada nalar dan pemahaman pengetahuan antara teori dengan praktiknya.

Universitas Prof. Hazairin (UNIHAZ) Bengkulu merupakan salah satu perguruan tinggi swasta yang mampu menghasilkan kaum intelektual yang berkualitas dan memiliki sikap dengan tatanan moral serta etika yang baik. Tugas utama mahasiswa adalah belajar, dimana dengan belajar setiap orang akan mendapatkan ilmu yang berguna bagi kehidupan di masa yang akan datang. Belajar merupakan proses dari yang tidak tahu menjadi tahu, yang tidak paham menjadi paham dan sebagainya seperti halnya saat memahami ilmu akuntansi.

Proses belajar sangat erat kaitannya dengan kecerdasan emosional, yaitu pengendalian diri. Pengendalian diri adalah kemampuan mengendalikan emosi diri sehingga berdampak positif pada pelaksanaan tugas, peka terhadap kata hati, sanggup menunda kenikmatan sebelum tercapainya suatu sasaran dan mampu segera pulih dari tekanan emosi. ( Goleman (2003) dalam Rachmi (2010;26).

Selain pengendalian diri faktor lain adalah perilaku belajar yang sesuai dengan tujuan pendidikan untuk terciptanya kemampuan akademis yang baik sehingga dapat melakukan pencapaian pada prestasi belajar mahasiswa. Mahasiswa harus dapat memahami akuntansi di tingkat pengantar sebelum melangkah ke tingkat pemahaman akuntansi yang lebih tinggi, sehingga harus didukung dengan perilaku belajar yang baik, semakin baik perilaku belajar pada seseorang maka akan semakin mudah dalam memahami mata kuliah pengantar akuntansi. (Sari,2013:6).

Penelitian ini mereplikasi dari penelitian yang dilakukan oleh Sari (2013), yang meneliti tentang pengaruh pengendalian diri dan perilaku belajar terhadap tingkat pemahaman pengantar akuntansi di Universitas Negeri Padang. Berdasarkan uraian di atas maka penulis tertarik mengambil judul "Pengaruh Pengendalian Diri dan Perilaku Belajar Terhadap Tingkat Pemahaman Pengantar Akuntansi ( studi empiris pada mahasiswa program studi akuntansi fakultas ekonomi Universitas Prof. Hazairin SH Kota Bengkulu)

\section{Rumusan Masalah}

Berdasarkan latar belakang di atas, maka rumusan masalah dalam penelitian ini adalah:

1. Apakah pengendalian diri berpengaruh pada tingkat pemahaman pengantar akuntansi pada mahasiswa program studi akuntansi Universitas Prof. Hazairin Kota Bengkulu?

2. Apakah perilaku belajar berpengaruh pada tingkat pemahaman pengantar akuntansi pada mahasiswa program studi akuntansi Universitas Prof. Hazairin Kota Bengkulu?

3. Apakah pengendalian diri dan perilaku belajar berpengaruh pada tingkat pemahaman pengantar akuntansi pada mahasiswa program studi akuntansi Universitas Prof. Hazairin Kota Bengkulu?

\section{Landasan Teori}

\section{Pemahaman Pengantar Akuntansi}

Accounting Principle Board (APB) Statement No. 4, mendefinisikan akuntansi merupakan suatu kegiatan jasa. Fungsinya adalah memberikan informasi kuantitatif, umumnya dalam ukuran uang, mengenai badan ekonomi yang dimaksudkan untuk digunakan dalam pengambilan keputusan ekonomi sebagai dasar memilih dari beberapa alternatif. (Harahap, Sofyan Syafri, 2011:5).

Menurut Perkins dalam Liviawati dan Aquino (2013:113), pemahaman adalah menunjukkan pada apa yang dapat seseorang lakukan dengan informasi, dari apa yang telah mereka ingat atau pelajari. 
Budhiyanto dan Ika Paskah (2004) dalam Yuniani (2010:22), tingkat pemahaman akuntansi mahasiswa dinyatakan dengan seberapa mengerti seorang mahasiswa terhadap apa yang sudah dipelajari yang dalam konteks ini mengacu pada mata kuliah akuntansi. Mahasiswa dapat dikatakan menguasai atau memahami akuntansi apabila ilmu akuntansi yang sudah diperolehnya selama ini dapat diterapkan dalam kehidupan bermasyarakat.

Berdasarkan definisi di atas dapat disimpulkan bahwa pemahaman akuntansi merupakan suatu proses atau cara mahasiswa dalam memahami, mempelajari dan menginterprestasikan kembali tentang konsep, teori dan pengaplikasian ilmu akuntansi secara benar.

\section{Pengendalian Diri}

Menurut Melandy dan Aziza (2006:11), pengendalian diri merupakan pengelolaan emosi yang berarti menangani perasaan agar dapat terungkap dengan tepat. Hal ini merupakan kecakapan yang sangat bergantung pada kesadaran diri. Emosi dikatakan berhasil dikelola apabila mampu menghibur diri ketika ditimpa kesedihan, dapat melepas kecemasan, kemurungan atau ketersinggungan dan bangkit kembali dengan cepat dari semua itu.

Heriningsih, $d k k$ (2005:82), tanggung jawab bagi seorang mahasiswa di lingkungan kampus adalah mengendalikan suasana hati mereka sendiri. Suasana hati bisa sangat berkuasa atas pikiran, ingatan dan wawasan

Pengendalian diri merupakan aspek yang perlu dilatih sejak dini. Manusia hendaknya menyadari bahwa emosi yang berlebihan atau tindakan yang hanya mengedepankan emosi saja dapat merusak untuk berfikir secara logis dan tidak bermanfaat baik bagi diri sendiri maupun orang lain.

\section{Perilaku Belajar}

Menurut Hanifah dan Syukri (2001:67), belajar yang efisien dapat dicapai apabila menggunakan strategi yang tepat, yakni adanya pengaturan waktu yang baik dalam mengikuti perkuliahan, belajar di rumah, berkelompok ataupun untuk mengikuti ujian. Perilaku belajar yang baik dapat terwujud apabila mahasiswa sadar akan tanggung jawab mereka sebagai mahasiswa sehingga mereka dapat membagi waktu mereka antara belajar dengan kegiatan di luar belajar.

Suwardjono (2004:38), terdapat empat indikator dari perilaku belajar adalah: kebiasaan mengikuti pelajaran, kebiasaan membaca buku, kunjungan ke perpustakaan dan kebiasaan menghadapi ujian.

\section{Kerangka Analisis}

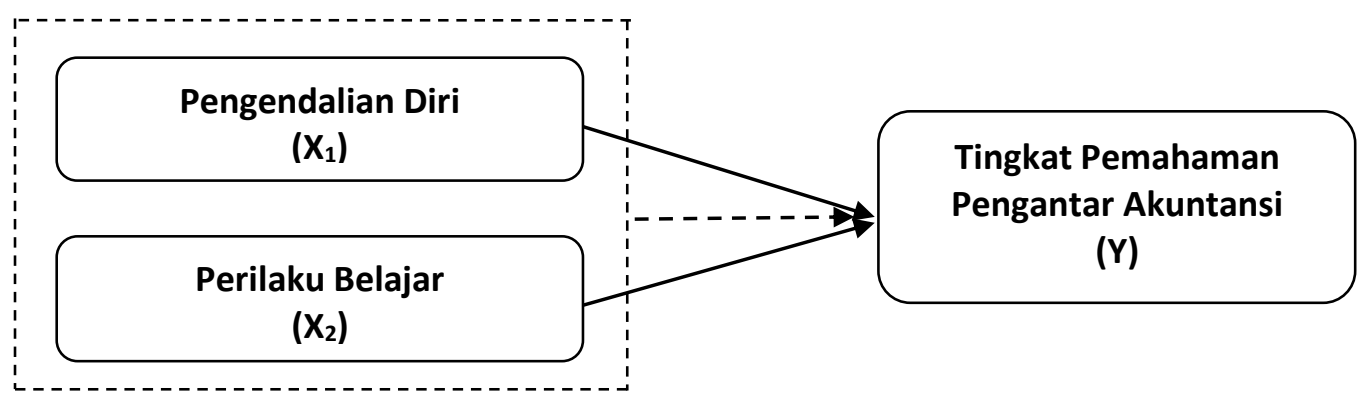

Gambar 1. Kerangka Analisis

Keterangan:

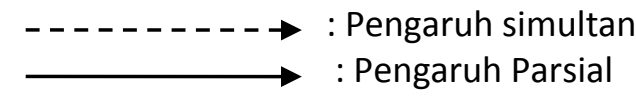




\section{Pengembangan Hipotesis}

\section{Pengendalian Diri Terhadap Tingkat Pemahaman Pengantar Akuntansi}

Penelitian yang dilakukan Yunaini (2010), Melandy RM, Dkk (2007) dan Heriningsih yang menyatakan bahwa pengendalian diri berpengaruh secara signifikan terhadap tingkat pemahaman pengantar akuntansi

Sari (2013:12) yang menyatakan bahwa pengendalian diri berpengaruh signifikan terhadap tingkat pemahaman pengantar akuntansi hal ini bermakna semakin tinggi tingkat pengendalian diri seorang mahasiswa maka akan semakin tinggi pula tingkat pemahaman pengantar akuntansi. Dari uraian di atas maka peneliti menyimpulkan hipotesis sebagai berikut: $\mathrm{H}_{1}=$ Pengendalian Diri Berpengaruh Terhadap Tingkat Pemahaman Pengantar Akuntansi

\section{Perilaku Belajar Terhadap Tingkat Pemahaman Pengantar Akuntansi}

Penelitian yang dilakukan Hanifah dan Abdullah (2001), yang menyatakan bahwa prilaku belajar berpengaruh secara signifikan terhadap prestasi belajar

Sari (2013:12) dan Rachmi (2010) yang menyatakan bahwa prilaku belajar berpengaruh signifikan terhadap tingkat pemahaman pengantar akuntansi hal ini bermakna semakin baik perilaku belajar seorang mahasiswa maka akan semakin baik pula tingkat pemahaman pengantar akuntansi. Dari uraian di atas maka peneliti menyimpulkan hipotesis sebagai berikut: $\mathrm{H}_{2}=$ Perilaku Belajar Berpengaruh Terhadap Tingkat Pemahaman Pengantar Akuntansi

\section{HASIL DAN PEMBAHASAN \\ Deskripsi Tingkat Pengembalian Kuisioner}

Pengembalian kuisioner yaitu menggambarkan keadaan responden apakah responden itu bisa memahami maksud dan keseriusan responden dalam menjawab setiap item pertanyaan-pertanyaan yang ada di dalam kuesioner tersebut. Untuk melihat tingkat deskriptif pengembalian kuesioner dapat dilihat pada tabel 1. di bawah ini :

\section{Tabel 1. Deskripsi Tingkat Pengembalian Kuesioner}

\begin{tabular}{|l|c|c|}
\hline Keterangan & Frekuensi & Persentase \\
\hline Kuesioner yang disebarkan & 100 & $100 \%$ \\
\hline Kuesioner yang tidak kembali & 39 & $39 \%$ \\
\hline Kuesioner yang Kembali & 61 & $61 \%$ \\
\hline Kuesioner yang siap diolah & 61 & $61 \%$ \\
\hline
\end{tabular}

Sumber : Data Diolah 2014

Berdasarkan uraian tabel 4.1 di atas, maka dapat dikatakan tingkat jumlah kuesioner yang telah disebarkan di Fakultas Ekonomi Jurusan Akuntansi Universitas Prof. Dr. Hazairin kuisioner 100 dengan tingkat persentase sebesar 100\%, sedangkan kuesioner yang tidak kembali sebanyak 39 kuesioner, dengan tingkat persentase sebesar 39\%, dan kuesioner yang siap diolah oleh peneliti adalah sebanyak 61 kuesioner dengan persentase sebesar $61 \%$.

\section{Uji Kualitas Data Uji Validitas}

Uji validitas digunakan untuk mengukur sah atau valid tidaknya suatu kuesioner. Suatu kuesioner dikatakan valid jika pernyataan pada kuesioner mampu mengungkapkan sesuatu yang akan diukur oleh kuesioner tersebut ( Ghozali, 2005:45). Dalam penelitian ini pengukuran validitas dilakukan dengan melakukan korelasi antar skor butir pertnyaan dengan total skor 
konstruk atau variabel. Untuk mengetahui uji validitas, dapat dilihat corrected item total correlation tampilan SPSS. Jika $r_{\alpha} \geq r_{\text {tabel }}$ berarti instrumen dinyatakan valid, sedangkan jika $r_{\alpha} \leq$ $\mathrm{r}_{\text {tabel }}$ berarti instrumen dinyatakan tidak valid. Hasil pengujian validitas dalam penelitian ini dapat dilihat dari tabel 2. berikut ini:

\section{Tabel 2. Hasil Uji Validitas Data}

\begin{tabular}{|c|c|c|}
\hline Variabel & Indikator Variabel & $\begin{array}{c}\text { Korelasi Variabel } \\
\text { Dengan Nilai } \\
\text { Totalnya } \\
\end{array}$ \\
\hline \multicolumn{3}{|c|}{ Pengendalian Diri $\left(\mathrm{X}_{1}\right)$} \\
\hline \multirow{4}{*}{$\begin{array}{l}\text { Pengendalian } \\
\text { Emosi }\end{array}$} & Saya kurang sabar dalam mengerjakan soal-soal pengantar akuntansi & 0,604 \\
\hline & Saya selalu memikirkan apa yang saya inginkan sebelum bertindak & 0,652 \\
\hline & Saya sering cepat bosan dan jenuh dalam melakukan sesuatu & 0,774 \\
\hline & $\begin{array}{l}\text { Demi mencapai prestasi belajar memuaskan, saya dapat menunda kesenanangan } \\
\text { sesaat saya, misalnya mengobrol, menonton TV, main game, jalan-jalan dll }\end{array}$ & 0,756 \\
\hline \multirow[b]{4}{*}{$\begin{array}{l}\text { Sifat Dapat } \\
\text { Dipercaya }\end{array}$} & Saya sangat memelihara norma kejujuran dalam hidup & 0,638 \\
\hline & Saya berlaku jujur saat menghadapi ujian & 0,685 \\
\hline & Saya tahu betul bagaimana kemampuan diri saya dalam penguasaan materi & 0,793 \\
\hline & $\begin{array}{l}\text { Saya malas mencoba mengerjakan soal akuntansi yang sama jika saya pernah gagal } \\
\text { saat mengerjakannya }\end{array}$ & 0,605 \\
\hline \multirow{4}{*}{ Kewaspadaan } & $\begin{array}{l}\text { Saya akan menyelesaikan tugas yang menjadi tanggung jawab saya, meskipun saya } \\
\text { tidak menyukainya }\end{array}$ & 0,893 \\
\hline & $\begin{array}{l}\text { Saya segera mengerjakan tugas yang telah diberikan oleh Dosen dengan tidak } \\
\text { mengulur waktu }\end{array}$ & 0,524 \\
\hline & Saya bertanggungjawab dengan apa yang telah saya lakukan & 0,893 \\
\hline & $\begin{array}{l}\text { Saya akan mengerjakan tugas meskipun ada kemungkinan tugas tersebut tidak } \\
\text { dikumpul atau dinilai dengan Dosen }\end{array}$ & 0,654 \\
\hline \multirow{4}{*}{ Adabtibilitas } & Saya berani tampil beda diantara teman-teman saya & 0,705 \\
\hline & $\begin{array}{l}\text { Saya senang menghadapi tantangan untuk dapat memecahkan masalah dan kasus } \\
\text { dalam mata kuliah pengantar akuntansi }\end{array}$ & 0,747 \\
\hline & $\begin{array}{l}\text { Saya mudah menyerah pada saat mengerjakan soal-soal akuntansi yang dianggap } \\
\text { sulit }\end{array}$ & 0,664 \\
\hline & $\begin{array}{l}\text { Saya lebih banyak dipengaruhi oleh rasa takut akan kegagalan dari pada harapan } \\
\text { untuk sukses dalam belajar }\end{array}$ & 0,642 \\
\hline \multirow{4}{*}{ Inovasi } & $\begin{array}{l}\text { Saya mudah menerima dan terbuka terhadap gagasan, pendekatan dan informasi- } \\
\text { informasi baru dalam ilmu akuntansi }\end{array}$ & 0,873 \\
\hline & $\begin{array}{l}\text { Saya tertarik dengan matakuliah yang menuntut saya untuk dapat memberi } \\
\text { gagasan baru dalam akuntansi }\end{array}$ & 0,679 \\
\hline & $\begin{array}{l}\text { Saya dapat menerima kritik dengan pikiran terbuka dan menerimanya bila hal itu } \\
\text { dapat dibenarkan }\end{array}$ & 0,873 \\
\hline & $\begin{array}{l}\text { Saya suka mencoba hal-hal baru dalam hidup saya terutama saat mengerjakan soal } \\
\text { akuntansi yang dianggap rumit }\end{array}$ & 0,557 \\
\hline \multicolumn{3}{|c|}{ Perilaku Belajar $\left(\mathrm{X}_{2}\right)$} \\
\hline \multirow{4}{*}{$\begin{array}{l}\text { Kebiasaan } \\
\text { Mengikuti } \\
\text { Pelajaran }\end{array}$} & Saya membuat catatan/pertanyaan saat perkuliahan berlangsung & 0,679 \\
\hline & $\begin{array}{l}\text { Saya meminta penjelasan kembali kepada dosen ketika saya merasa belum } \\
\text { mengerti dan memahami materi }\end{array}$ & 0,873 \\
\hline & Saya mengejar ketertinggalan materi saat berhalangan hadir & 0,873 \\
\hline & $\begin{array}{l}\text { Demi mendiskusikan materi terkait dengan pengantar akuntansi dengan teman saat } \\
\text { perkuliahan }\end{array}$ & 0,557 \\
\hline \multirow{4}{*}{$\begin{array}{l}\text { Kebiasaan } \\
\text { Membaca Buku }\end{array}$} & Saya mempersiapkan materi sebelum perkuliahan berlangsung & 0,931 \\
\hline & Saya membaca buku pengantar akuntansi sampai mengerti & 0,743 \\
\hline & Saat membaca saya memberi tanda pada bagian yang saya anggap penting & 0,662 \\
\hline & $\begin{array}{l}\text { Saya merasa ada keharusan dalam diri saya untuk membaca buku akuntansi agar } \\
\text { saya lebih mengerti }\end{array}$ & 0,931 \\
\hline \multirow{4}{*}{$\begin{array}{l}\text { Kunjungan } \\
\text { Ke Perpustakaan }\end{array}$} & Saya memanfaatkan waktu luang saya untuk ke perpustakaan & 0,771 \\
\hline & $\begin{array}{l}\text { Saya sering menghabiskan waktu diperpustakaan untuk membaca dan berdiskusi } \\
\text { dengan teman terkait dengan materi akuntansi }\end{array}$ & 0,707 \\
\hline & Saya meminjam buku setiap kali ke perpustakaan & 0,733 \\
\hline & Saya sering memfoto kopi buku yang dipinjam untuk tambahan ilmu & 0,684 \\
\hline \multirow{4}{*}{$\begin{array}{l}\text { Kebiasaan } \\
\text { Mengikuti Ujian }\end{array}$} & Saya selalu membuat catatan secara teratur & 0,763 \\
\hline & Saya belajar dengan teratur, baik dan disiplin & 0,734 \\
\hline & Saya mengatur waktu belajar lebih banyak sebelum menghadapi ujian & 0,767 \\
\hline & $\begin{array}{l}\text { Saya telah melakukan berbagai persiapan terkait dengan materi yang akan diujikan } \\
\text { jauh sebelum ujian akan berlangsung }\end{array}$ & 0,768 \\
\hline
\end{tabular}

\section{**Correlation is significant at the 0.01 level (2-tailed)}

\section{Sumber data diolah 2014}


Dari tabel 2. di atas dapat dilihat bahwa variabel pengendalian diri dan perilaku belajar adalah valid. Dengan demikian syarat validitas dari alat ukur terpenuhi.

\section{Uji Reliabilitas}

Uji reliabilitas adalah alat untuk mengukur suatu kuesioner yang merupakan indikator dari variabel atau konstruk. Suatu kuesioner dikatakan reliabel atau handal apabila jawaban responden terhadap pertanyaan adalah konsisten dari waktu ke waktu. Dalam uji reliabilitas menggunakan konsistensi interkorelasi yaitu teknik Cronbach's Alpha $(\alpha)$, koefisien alpha $(\alpha)$ dapat digunakan untuk menganalisa multipoint scaled items. Apabila Cronbach's Alpha dari hasil pengujian di atas 0,6 maka dapat dikatakan bahwa konstruk atau variabel adalah reliabel (Ghozali, 2005: 56). ini :

Dari hasil pengujian reliabilitas dalam penelitian ini dapat dilihat pada Tabel 3. berikut

\section{Tabel 3. Hasil Uji Reliabilitas}

\begin{tabular}{|l|c|c|c|}
\hline Variabel & Nilai Cronbach Alpha & Nilai Kritis & Keterangan \\
\hline Pengendalian Diri & 0,648 & 0,6 & Reliabel \\
\hline Pengendalian Emosi & 0,614 & 0,6 & Reliabel \\
\hline Sifat Dapat Dipercaya & 0,734 & 0,6 & Reliabel \\
\hline Kewaspadaan & 0,633 & 0,6 & Reliabel \\
\hline Adabtibilitas & 0,723 & 0,6 & Reliabel \\
\hline Inovasi & \multicolumn{3}{|l|}{} \\
\hline Perilaku Belajar & 0,723 & 0,6 & Reliabel \\
\hline Kebiasaan Mengikuti Pelajaran & 0,825 & 0,6 & Reliabel \\
\hline Kebiasaan Membaca Buku & 0,695 & 0,6 & Reliabel \\
\hline Kunjungan Ke Perpustakaan & 0,751 & 0,6 & Reliabel \\
\hline Kebiasaan Menghadapi Ujian &
\end{tabular}

Sumber : Data diolah 2014

Berdasarkan Tabel 3 diketahui bahwa variabel variabel pengendalian diri dan perilaku belajar memiliki nilai cronbach alpha yang lebih tinggi dari 0,6 maka dikatakan reliabel. Dengan demikian syarat reliabilitas alat ukur terpenuhi.

\section{Analisis Regresi Linier Logistik}

Pengujian hipotesis satu dan dua dalam penelitian ini menggunakan regresi logistik dimana sebelum dilakukan pengujian terhadap ketiga hipotesis tersebut, terlebih dahulu akan dilakukan uji kelayakan model. Hasil regresi dengan menggunakan logistic regression disajikan pada Table 4. di bawah ini:

Tabel 4. Hasil Pengujian Hipotesis Dengan Menggunakan Regresi Logistik

\begin{tabular}{|l|c|c|c|}
\hline \multicolumn{1}{|c|}{ Variabel } & Nilai Koefisien & Wald (t) & Sig. \\
\hline Constant & 7,560 & 4,744 & 0.029 \\
\hline Pengendalian Diri & $-0,136$ & 7,392 & 0.007 \\
\hline Perilaku Belajar & 0,058 & 0,649 & 0.420 \\
\hline -2 Log Likelihood Intercept Only & 83,759 & & \\
\hline -2 Log Likelihood Final & 5,545 & & \\
\hline Chi-Square & 10,082 & & \\
\hline Sig. & 0.259 & & \\
\hline Pseudo R-Square Nagelkerke & 0.968 & & \\
\hline
\end{tabular}

Sumber : data diolah tahun 2014 
Sebelum dilakukan pengujian terhadap kedua hipotesis yang menggunakan regresi logistik terlebih dilakukan uji kelayakan model. Uji kelayakan model pada regresi logistic adalah dengan melihat nilai -2 Log Likelihood Intercept Only dengan -2 Log Likelihood Final. Suatu model regresi logistik dikatakan baik jika terjadi penurunan nilai dari -2 Log Likelihood Intercept Only dengan nilai -2 Log Likelihood Final dan penurunannya adalah signifikan.

Hasil regresi logistik yang disajikan pada tabel menunjukkan bahwa nilai -2 Log Likelihood Intercept Only sebesar 83,759 dan nilai -2 Log Likelihood Final adalah sebesar 5,545. Dengan membandingkan nilai tersebut dapat disimpulkan bahwa model regresi yang digunakan dalam penelitian ini adalah sangat baik yang ditunjukkan dengan penurunan nilai -2 Log Likelihood Intercept Only dan -2 Log Likelihood Final dan penurunannya adalah signifikan pada level $1 \%(\rho$-value $<5 \%)$ dengan nilai chi-square sebesar 10,082 .

Hasil regresi selanjutnya menunjukkan bahwa seluruh variabel independen yang digunakan dalam penelitian ini mampu menjelaskan pengaruhnya terhadap variabel dependen yaitu tingkat pemahaman pengantar akuntansi (nilai ujian) sebesar 96,8\% yaitu yang ditunjukkan dengan nilai Pseudo R-Square Nagelkerke sebesar 0.968 dan sisanya sebesar $3,2 \%$ dijelaskan oleh variabel lainnya yang tidak dimasukkan ke dalam persamaan.

Untuk pengujian hipotesis pertama yang bertujuan untuk membuktikan bahwa pengendalian diri berpengaruh terhadap tingkat pemahaman pengantar akuntansi, hasil regresi menunjukkan bahwa koefisien regresi dari pengendalian diri adalah negatif sebesar 0,136 yang berarti bahwa semakin turun pengendalian diri yang dimiliki seorang mahasiswa maka akan maka akan menurunkan dalam pemahaman pengantar akuntansi. Koefisien regresi yang negatif dan signifikan $(0,007<5 \%$ dari variabel pengendalian diri, maka hipotesis pertama dalam penelitian ini diterima.

Dengan diterimanya hasil penelitian ini mengindikasikan bahwa variabel pengendalian diri bisa dijadikan ukuran dalam menilai seorang mahasiswa terhadap tingkat pemahaman pengantar akuntansi di perguruan tinggi.

Untuk pengujian hipotesis kedua yang bertujuan untuk mengetahui perilaku belajar terhadap tingkat pemahaman pengantar akuntansi, hasil regresi menunjukkan bahwa koefisien regresi dari kecerdasan spritual adalah sebesar 0,058 yang berarti bahwa kecerdasan spritual berpengaruh terhadap tingkat pemahaman pengantar akuntansi. Koefesien yang positif dan tidak signifikan $(0,420>5 \%)$ maka hipotesis kedua dinyatakan ditolak.

Dengan ditolaknya hipotesis ini berarti bahwa perilaku belajar belum bisa dijadikan ukuran bagi seorang mahasiswa dalam tingkat pemahaman pengantar akuntansi.

\section{Pembahasan}

Hipotesis pertama dalam penelitian ini yang menguji pengaruh pengendalian diri terhadap tingkat pemahaman pengantar akuntansi di Fakultas Ekonomi Jurusan Akuntansi Universitas Prof. Dr. Hazairin Bengkulu Kota Bengkulu berpengaruh dan signifikan terhadap tingkat pemahaman pengantar akuntansi, oleh karena itu hipotesis pertama dalam penelitian ini diterima.

Hasil penelitian ini sesuai dengan penelitian yang dilakukanb oleh Penelitian yang dilakukan Yunaini (2010), Melandy RM, Dkk (2007) dan Heriningsih yang menyatakan bahwa pengendalian diri berpengaruh secara signifikan terhadap tingkat pemahaman pengantar akuntansi. Serta penelitian yang juga dilakukan oleh Sari (2013:12) yang menyatakan bahwa pengendalian diri berpengaruh signifikan terhadap tingkat pemahaman pengantar akuntansi hal ini bermakna semakin tinggi tingkat pengendalian diri seorang mahasiswa maka akan semakin tinggi pula tingkat pemahaman pengantar akuntansi

Hipotesis kedua dalam penelitian ini yang menguji pengaruh variabel perilaku belajar terhadap tingkat pemahaman pengantar akuntansi di fFakultas Ekonomi Jurusan Akuntansi Universitas Prof. Dr. Hazairin Bengkulu Kota Bengkulu berpengaruh dan tidak signifikan terhadap tingkat pemahaman pengantar akuntansi, oleh karena itu hipotesis dalam penelitian ini ditolak 
Hasil penelitian tidak sesuai dengan penelitian yang dilakukan oleh Penelitian yang dilakukan Hanifah dan Abdullah (2001), yang menyatakan bahwa prilaku belajar berpengaruh secara signifikan terhadap prestasi belajar dan penelitian yang dilakukan juga oleh Sari (2013:12) dan Rachmi (2010) yang menyatakan bahwa prilaku belajar berpengaruh signifikan terhadap tingkat pemahaman pengantar akuntansi hal ini bermakna semakin baik perilaku belajar seorang mahasiswa maka akan semakin baik pula tingkat pemahaman pengantar akuntansi.

\section{Kesimpulan}

Berdasarkan hasil pengolahan data di atas maka dapat ditarik kesimpulan :

1. Pengendalian diri berpengaruh dan signifikan terhadap tingkat pemahaman akuntansi, hal ini ditunjukkan dengan nilai koefisien $\beta$ sebesar 0,136 pada tingkat signifikan 0,007 , karena tingkat signifikan $0.007<0.05$. Dengan diterimanya hipotesis ini maka variabel pengendalian diri bisa dijadikan ukuran dalam tingkat pemahaman akuntansi.

2. Perilaku Belajar berpengaruh dan tidak signifikan terhadap tingkat pemahaman akuntansi, hal ini ditunjukkan dengan nilai koefisien $\beta$ sebesar 0,058 pada tingkat signifikan 0,420, karena tingkat signifikan $0,420>0.05$ maka variabel perilaku belajar berpengaruh dan tidak signifikan terhadap variabel tingkat pemahaman akuntansi. Dengan ditolaknya hipotesis ini berarti variabel perilaku belajar belum bisa dijadikan ukuran dalam tingkat pemahaman akuntansi.

3. Pengendalian diri dan Perilaku Belajar berpengaruh dan signfikan terhadap tingkat pemahaman akuntansi bahwa nilai pseudo R-Square Nagelkerke sebesar 0,968 * Hal ini berarti bahwa variabel pengendalian diri dan perilaku belajar dapat dijelaskan dalam penelitian ini sebesar 96,8\% sedangkan sisanya sebesar 3,2\% dijelaskan oleh variabel lain yang tidak dimasukkan dalam penelitian ini.

\section{Saran}

Adapun saran dalam penelitian ini adalah:

1. Untuk lebih meningkatkan pengendalian diri bagi mahasiswa sehingga mahasiswa diharapkan memperoleh kepuasan terhadap apa yang menjadi tujuan kuliah di sebuah perguruan tinggi

2. Untuk lebih meningkatkan perilaku belajar bagi mahasiswa sehingga mahasiswa dapat merubah pola belajar dengan cara berdiskusi dengan teman, dosen atau yang lain sehingga dapat memperoleh pengalaman baru

3. Untuk penelitian selanjutnya hendaknya menambahkan variabel lain seperti kecerdasan emosional, kecerdasan spiritual dan kepercayaan diri.

\section{DAFTAR PUSTAKA}

Aquino, Afvan dan Liviawati,2013. Pengaruh Kecerdasan Emosional Terhadap Tingkat Pemahaman Akuntansi Ditinjau dari Perspektif Gender. Pekbis Jurnal, Vol 5, No. 2, Juli 2013:111-121

Ghozali, 2005. Aplikasi Multivariat dengan Program IBM SPSS. Semarang: Badan Penerbit Universitas Diponegoro.

Hanifah dan Syukri Abdullah, 2001. Pengaruh Perilaku Belajar Terhadap Prestasi Akademik Mahasiswa Akuntansi. Media Riset Akuntansi, Auditing dan Informasi, Vol 1, No. 3, 63-86 
Harahap, Sofyan Syafri. 2011.Teori Akuntansi, Edisi Revisi 2011, Jakarta:PT Gramedia Pustaka Utama

Heriningsih, Sucahyo, Sri Suryaningrum dan Windiyastuti 2005. Pengaruh Kecerdasan Emosional pada Pemahaman Akuntansi di Tingkat Pengantar dengan Penalaran dan Pendekatan. Jurnal Akuntansi dan Manajemen, Vol XVI, No.2, 79-92

Indriantoro Nur dan Bambang Supomo. 2002. Metodologi Penelitian Bisnis Untuk Akuntansi dan Manajemen, Edisi Pertama. Yogyakarta : BPFE Yogyakarta

Melandy, Rissyo dan Nurna Aziza, 2006. Pengaruh Kecerdasan Emosional Terhadap Tingkat Pemahaman Akuntansi, Kepercayaan Diri Sebagai Variabel Pemoderasi. Jurnal Simposium Nasional Akuntansi 9, Padang, 23- 26 Agustus.

Narbuko, Cholid dan Abu Achmadi.2007. Metodelogi Penelitian. Cetakan Kedelapan. Jakarta:PT Bumi Aksara

Sari, Yora Komala,2013.Pengaruh Pengendalian Diri dan Perilaku Belajar Terhadap Tingkat Pemahaman Pengantar Akuntansi di Universitas Negeri Padang. Jurnal Fakultas Ekonomi.UNP: Padang

Sugiyono, 2004. Metode Penelitian Bisnis. Penerbit: Alfabet, Bandung.

Suwardjono, 2004. Perilaku Belajar di Perguruan Tinggi. Jurnal Akuntansi dan Manajemen. Maret. STIE YKPN. Yogyakarta

Yunani, Anggun. 2010.Pengaruh Kecerdasan Emosional Terhadap Tingkat Pemahaman Akuntansi. Jurnal Fakultas Ekonomi Universitas Diponegoro. Semarang 